\title{
Healthy Subject Indicator
}

National Cancer Institute

\section{Source}

National Cancer Institute. Healthy Subject Indicator. NCI Thesaurus. Code C98737.

Specifies whether an individual who is or becomes a participant in a research study and has no significant health-related issues including those related to the condition being tested. 